MaPan : Jurnal Matematika dan Pembelajaran

p-ISSN: 2354-6883 ; e-ISSN: 2581-172X

Volume 5, No 2, December 2017 (279-292)

DOI: https://doi.org/10.24252/mapan.v5n2a9

\title{
PENGARUH PENGUASAAN KONSEP TEOREMA PYTHAGORAS TERHADAP KEMAMPUAN MENYELESAIKAN SOAL-SOAL BANGUN RUANG SISI DATAR PADA SISWA KELAS VIII MTS NEGERI BALANG-BALANG
}

\author{
Syahrida Zaerani1), Mardhiah2), Suharti ${ }^{3)}$ \\ 1,2,3Universitas Islam Negeri Alauddin Makassar \\ Kampus: Jalan H. M. Yasin Limpo No. 36 Samata-Gowa \\ E-mail: zaeranidarwis@gmail.co.id1), mardhiah.diah@uin-alauddin.ac.id²), \\ suharti.harti@uin-alauddin.ac.id3)
}

\begin{abstract}
Abstrak:
Penelitian ini bertujuan untuk mengetahui pengaruh penguasaan konsep teorema Pythagoras terhadap kemampuan menyelesaikan soal-soal bangun ruang sisi datar pada siswa kelas VIII MTs Negeri Balang-Balang. Penelitian ini adalah penelitian kuantitatif jenis ex post facto. Populasi yaitu seluruh siswa kelas VIII MTs Negeri Balang-Balang yang berjumlah 204 siswa. Adapun sampelnya berjumlah 102 orang yang diambil melalui teknik simple random sampling. Instrumen penelitian berupa tes soal Pythagoras dan soal bangun ruang sisi datar. Teknik analisis yang digunakan adalah analisis statistik deskriptif dan analisis statistik inferensial yaitu dengan regresi linear sederhana. Hasil analisis deskriptif menunjukkan bahwa penguasaan konsep teorema Pythagoras dan kemampuan menyelesaikan soal-soal bangun ruang sisi datar masing-masing berada pada kategori tinggi. Adapun hasil analisis statistik inferensial pada regresi linear sederhana menunjukkan bahwa terdapat pengaruh antara penguasaan konsep teorema Pythagoras terhadap kemampuan menyelesaikan soalsoal bangun ruang sisi datar siswa kelas VIII MTs Negeri Balang-Balang.
\end{abstract}

Kata Kunci: Penguasaan Konsep, Teorema Pythagoras, Bangun Ruang Sisi Datar

\section{THE IMPACT OF THE MASTERY OF PYTHAGOREAN THEOREM CONCEPTS ON POLYHEDRON PROBLEM SOLVING ABILITY OF GRADE VIII STUDENTS OF MTS NEGERI BALANG-BALANG}

\begin{abstract}
:
This study aims to determine the impact of the mastery of Pythagoras Theorem concepts on the ability of MTs Negeri Balang-Balang grade VIII students to solve polyhedron problems. This study is a quantitative research with ex post facto design. Statistical population consists of all grade VIII students in MTs Negeri Balang-Balang which was 204 students. The number of sampling used is 102 respondents taken by simple random sampling technique. The research instrument was a test related to Pythagorean an polyhedron problems. Descriptive and inferential statistics were performed as the statistical analysis. The descriptive analysis result shows that the mastery of Pythagoras Theorem concepts is within the category of 'high' and the ability of solving polyhedron problems is as well. The inferential statistical analysis using simple linear regression shows that there is an impact of the mastery of Pythagoras Theorem concepts on polyhedron problem solving ability of Grade VIII students of MTs Negeri Balang-Balang.
\end{abstract}


Keywords: Mastery of Concepts, Pythagoras Theorem, Polyhedron

How to Cite: Zaerani, S., Mardhiah, \& Suharti. (2017). Pengaruh Penguasaan Konsep Teorema Pythagoras terhadap Kemampuan Menyelesaikan Soal-Soal Bangun Ruang Sisi Datar Pada Siswa Kelas VIII MTs Negeri Balang-Balang. MaPan : Jurnal Matematika dan Pembelajaran, 5(2), 279-292.

$\mathrm{P}$ endidikan adalah salah satu faktor penunjang berkembangnya sebuah bangsa. Kualitas pendidikan tentu akan berdampak baik atau buruk terhadap suatu bangsa. Salah satu penunjang keberhasilan pendidikan berada ditangan guru, orang tua, dan pemerintah dalam hal ini menteri pendidikan. Sasaran utama sebuah pendidikan adalah manusia. Pendidikan itu merupakan suatu keharusan, karena dengan pendidikan kita akan memiliki kemampuan dan kepribadian yang berkembang, kita ingin agar terus berusaha meningkatkan, mengembangkan dan memperbaiki nilai-nilai, perasaan, pengetahuan dan keterampilan.

Pendidikan merupakan salah satu bentuk kegiatan manusia dalam kehidupannya, yang menetapkan tujuan yang ingin dicapai, baik tujuan bersifat abstrak sampai pada rumusan-rumusan yang dibentuk secara khusus untuk memudahkan pencapaian tujuan yang lebih tinggi (Danim, 2010), begitu juga dikarenakan pendidikan merupakan bimbingan terhadap perkembangan manusia menuju kearah cita-cita tertentu, maka yang menjadi masalah pokok dalam sebuah pendidkan adalah memilih arah yang ingin dicapai (Tirtarahrdja dan Sulo, 2015). Pendidikan yang dilaksanakan tanpa tujuan akan berakhir dengan kegagalan. Oleh karena itu, tujuan pendidikan telah ditetapkan dalam UU No. 20 tahun 2003 tentang Sisdiknas, yang disebutkan bahwa pendidikan bertujuan untuk mengembangkan potensi peserta didik agar menjadi manusia yang beriman dan bertakwa kepada Tuhan yang Maha Esa, berakhlak mulia, sehat, berilmu, cakap, kreatif, mandiri, dan menjadi warga Negara yang demokratis serta bertanggung jawab.

Belajar bukan hanya sekedar menghafal namun kita harus mengaitkan konsep yang sudah ada dengan pengetahuan baru agar kita lebih cepat memaknainya (Dahar, 2011). Matematika adalah salah satu ilmu pengetahuan yang sangat penting karena merupakan induk dari ilmu pengetahuan lainnya, dan memiliki banyak manfaat dalam kehidupan sehari-hari. Pembelajaran matematika bukan hanya mengetahui tentang bagaimana cara berhitung, 
namun kita juga harus mengetahui tentang konsep matematika yang berkenan dengan ide-ide yang bersifat abstrak (Putra dkk, 2014). Oleh karena itu diperlukan sebuah metode atau strategi dalam menyampaikan materi matematika yang abstrak itu menjadi konkret, selanjutnya dari permasalahan yang konkret tersebut baru dialihkan kebentuk konsep-konsep matematika yang abstrak (Afifah, 2013). Bagi Ausebel belajar bermakna merupakan suatu proses mengaitkanya pengetahuan baru dengan konsep-konsep yang sesuai yang terdapat pada struktur koginitif seseorang.

Salah satu materi yang sering dijumpai adalah teorema Pythagoras, apabila peserta didik telah mampu menguasai konsep Pythagoras maka siswa akan lebih mudah menyelesaikan soal-soal yang berkaitan dengan teorema Pythagoras diantaranya yaitu penyelesaian soal-soal bangun ruang sisi datar, baik itu mencari diagonal ruang dan diagonal bidangnya, menentukan luas dan volumenya, jadi pada dasarnya teorema Pythagoras adalah materi prasyarat untuk bisa menyelesaikan soal-soal yang terkait dengan bangun ruang sisi datar.

Berdasarkan observasi yang dilakukan di MTs. Negeri Balang-Balang, melalui wawancara dengan Asiah selaku guru matematika di sekolah tersebut, diperoleh bahwa daya tangkap siswa dalam memperoleh pelajaran berbedabeda sehingga beberapa siswa yang pernah diajar masih ada yang bingung dalam menyelesaikan soal-soal yang berkaitan dengan teorema Pythagoras, namun ada banyak siswa yang juga sudah menguasai konsep Pythagoras. Hal ini bisa dibuktikan dengan persentase hasil belajar siswa kelas VIII.1-VIII.4 dalam menyelesaikan soal teorema Pythagoras. Siswa yang memperoleh nilai kurang dari 65 yang dikategorikan kurang sebanyak 26\%, yang memperoleh nilai lebih dari 65-70 yang dikategorikan cukup sebanyak $11 \%$, yang memperoleh nilai lebih 70-80 yang dikategorikan baik sebanyak $24 \%$, dan yang memperoleh nilai lebih dari 80 yang dikategorikan sangat baik sebanyak $36 \%$. Salah satu penyebab siswa mendapat nilai yang rendah dikarenakan masih ada siswa yang belum menguasai konsep dari teorema Pythagoras itu sendiri, sehingga diakibatkan nantinya kurang mampu meyelesaikan soal yang menggunakan teorema Pythagoras, khususnya pada materi bangun ruang. Untuk mengetahui kebenaran dari hal tersebut, peneliti mencoba untuk menyelidiki apakah penguasaan konsep teorema Pythagoras yang merupakan materi prasyarat bangun ruang sisi datar memang berpengaruh dalam menyelesaikan soal-soal bangun ruang sisi datar. 
Berdasarkan penelitian relevan sebelumnya yang dilakukan Muchyidin, dkk. (2012) menyimpulkan bahwa terdapat pengaruh penguasaan teorema Pythagoras terhadap kemampuan siswa dalam menyelesaikan soal-soal garis singgung lingkaran. Adapun nilai koefisien korelasi mencapai 0,978 sedangkan koefisien determinasinya mencapai 63,3\%, dengan kata lain penguasaan teorema Pythagoras merupakan materi prasyarat dari materi garis singgung lingkaran dengan konstribusi sebesar 63,6\%

Uraian di atas memerlukan adanya penelitian yang bertujuan untuk mengetahui pengaruh penguasaan konsep teorema Pythagoras terhadap kemampuan menyelesaikan soal-soal bangun ruang sisi datar.

\section{PENGERTIAN MATEMATIKA}

Menurut Anitah dkk, dalam buku Hamzah dan Muhlisrarini (2014) menerangkan bahwa matematika adalah ilmu tentang logika terkait mengenai bentuk, susunan besaran, dan konsep-konsep hubungan lain yang jumlahnya banyak dan terbagi kedalam tiga bidang yaitu aljabar, analisis, dan geometri. Matematika memegang peran penting dalam mengembangkan kemampuan menyelesaikan masalah dan kemampuan berpikir kritis pada siswa. Konsep matematika menjadi hal terpenting untuk dikuasai karena penggunaannya yang luas dimasa depan dan banyak digunakan dalam mata pelajaran yang lain (Rohim, 2011). Selain itu pembelajaran matematika dapat meningkatkan kemampuan berpikir, memberikan banyak manfaat dalam penyelesaian masalah sehari-hari, dan sangat mendukung perkembangan ilmu pengetahuan. Oleh karena itu matematika merupakan ilmu dasar yang harus dikuasai.

Berdasarkan berbagai pendapat tentang definisi dan deskripsi matematika di atas, benar-benar menunjukkan begitu luasnya objek kajian dalam matematika. Jadi dapat disimpulkan bahwa matematika adalah ilmu pengetahuan yang terdiri atas beberapa bagian yang memiliki keterkaitan dengan beberapa disiplin ilmu yang lain dan dalam proses penyelesaiannya membutuhkan pemikiran secara logis.

\section{TEORI AUSUBEL}

Menurut teori Ausubel, belajar dapat didefinisikan ke dalam dua dimensi. Dimensi pertama terkait mengenai cara informasi atau materi pelajaran yang bisa disajikan pada siswa melalui penerimaan atau penemuan. Dimensi kedua terkait cara siswa mengaitkan informasi baru dengan informasi yang telah ada pada sturuktur kognitif seseorang. Struktur kognitif ialah fakta, 
konsep, dan generalisasi yang telah dipelajari dan diingat oleh siswa (Susanto, 2013). Inti teori Ausubel tentang belajar ialah belajar bermakna, yakni mengaitkannya informasi baru pada konsep yang sesuai yang ada pada struktur kognitif seseorang.

Berdasarkan teori Ausubel, dalam membantu siswa memahami materi baru, sangat penting untuk mengaitkan konsep-konsep awal yang telah dikuasai dengan konsep materi yang akan dipelajari oleh siswa, sehingga jika dikaitkan dengan model pembelajaran masalah, siswa akan mampu mengerjakan permasalahan yang autentik karena konsep awal yang sudah dimiliki siswa sebelumnya dapat menyelesaikan permasalahan yang nyata.

\section{PENGUASAAN KONSEP}

Penguasaan konsep dapat didefinisikan sebagai kemampuan siswa untuk memahami bermacam-macam konsep sebelum, selama dan setelah proses pembelajaran. Penguasaan konsep merupakan bagian dari pembelajaran yang termasuk dalam ranah kognitif. Namun keberhasilan proses pembelajaran tidak hanya tergantung pada ranah kognitif, tetapi juga tergantung pada lingkungan, kondisi belajar dan pengetahuan dasar siswa.

Penguasaan konsep merupakan salah satu kecakapan matematika. Pemahaman dan penguasaan konsep peserta didik mampu untuk menguasai konsep, operasi dan relasi matematis. Kecakapan ini dapat dicapai dengan memperhatikan indikator-indikator sebagai berikut:

a. Mampu menyatakan ulang sebuah konsep.

b. Mampu mengklasifikasikan objek menurut sifat-sifat tertentu sesuai dengan konsepnya.

c. Mampu memberikan contoh dan bukan contoh dari sebuah konsep.

d. Mampu untuk menyajikan konsep dari berbagai bentuk representasi matematis.

e. Mampu menggunakan, memanfaatkan dan memilih prosedur atau operasi tertentu.

f. Mampu mengaplikasikan konsep dalam pemecahan masalah

Penguasaan konsep yang dimaksud dalam penelitian ini adalah ketika siswa mampu menggunakan konsep-konsep dasar yang telah diperoleh dalam menyelesaikan suatu permasalahan dan telah mampu memenuhi beberapa indikator dalam pengusaan konsep.

\section{TEOREMA PYTHAGORAS}


Pythagoras adalah seorang ahli matematika dan filsafat berkebangsaan Yunani yang hidup pada tahun 569-475 SM. Sebagai ahli matematika, ia mengungkapkan bahwa kuadrat panjang sisi miring suatu segitiga siku-siku adalah sama dengan jumlah kuadrat panjang sisi-sisi yang lain (Sood, 2013). Untuk menentukan teorema pythagoras, ada beberapa langkah yang dilakukan. Ambillah dua potong kertas berbentuk persegi berukuran $(b+c) \mathrm{cm}$.

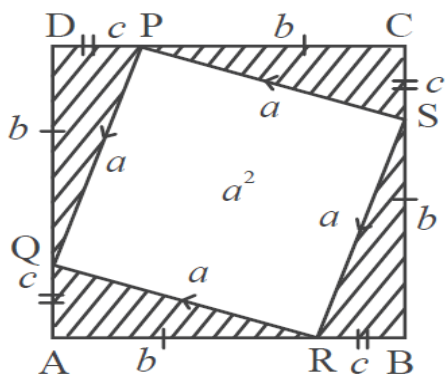

Gambar diatas menunjukkan persegi ABCD berukuran $(a+b) \mathrm{cm}$. Pada keempat sudutnya, dibuat empat segitiga siku-siku dengan panjang sisi sikusikunya $\mathrm{b} \mathrm{cm}$ dan $\mathrm{c} \mathrm{cm}$. Luas persegi $\mathrm{ABCD}$ sama dengan luas persegi (luas daerah yang tidak diarsir) ditambah luas empat segitiga siku-siku (luas daerah yang diarsir), sehingga diperoleh

Luas daerah yang diarsir $=$ Luas empat segitiga siku-siku

$$
\begin{aligned}
& =4 \times \frac{1}{2} \times a \times t \\
& =2 b c
\end{aligned}
$$

Luas daerah yang tidak diarsir $=$ Luas persegi $\mathrm{PQRS}$

$$
\begin{aligned}
& =a \times a \\
& =a^{2}
\end{aligned}
$$

Selanjutnya buatlah persegi EFGH berukuran $(b+c) c m$ seperti di bawah ini. 


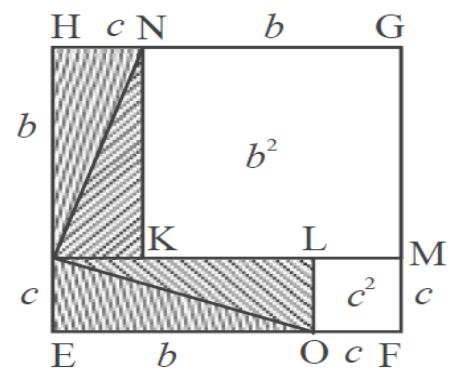

Pada dua buah sudutnya, dibuat empat segitiga siku-siku sedemikian sehingga membentuk dua persegi panjang berukuran $(\mathrm{b} \times \mathrm{c}) \mathrm{cm}$. Luas persegi EFGH sama dengan luas persegi (luas daerah yang tidak diarsir) ditambah luas empat segitiga siku-siku (luas daerah yang diarsir), sehingga diperoleh

Luas daerah yang diarsir = luas dua persegi panjang

$$
\begin{aligned}
& =2 \times b \times c \\
& =2 b c
\end{aligned}
$$

Luas daerah yang tidak diarsir = luas persegi KMGN + luas persegi OFML

$$
\begin{aligned}
& =(b \times b)+(c \times c) \\
& =b^{2}+c^{2}
\end{aligned}
$$

Dari penjelasan sebelumnya terlihat bahwa ukuran persegi $\mathrm{ABCD}=$ ukuran persegi EFGh, sehingga diperoleh

Luas persegi $\mathrm{ABCD}=$ Luas persegi $\mathrm{EFGH}$

$$
\begin{aligned}
2 b c+a^{2} & =2 b c+b^{2}+c^{2} \\
a^{2} & =b^{2}+c^{2}
\end{aligned}
$$

Kesimpulannya, luas daerah yang panjang sisinya adalah sisi miring suatu segitiga siku-siku sama dengan jumlah luas daerah persegi yang panjang sisinya adalah siku-siku segitiga.

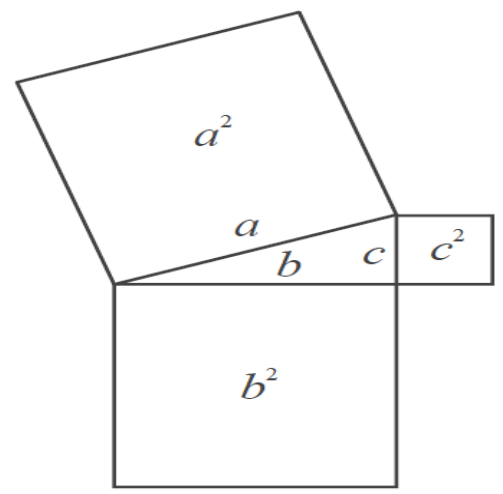


Kesimpulan tersebut selanjutnya dikenal dengan teorema Pythagoras. Yang dirumuskan sebagai berikut:

Untuk setiap segitiga siku-siku berlaku kuadrat panjang sisi miring sama dengan jumlah kuadrat panjang sisi lainnya.

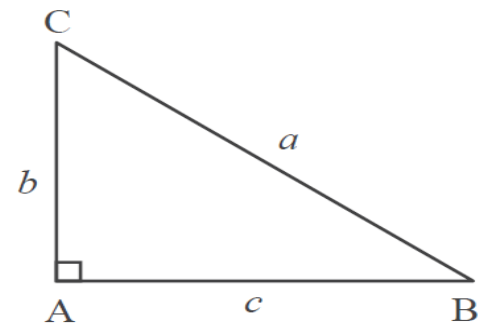

Gambar segitiga ABC di atas adalah segitiga siku-siku dengan a panjang sisi miring, sedangkan $b$ dan $c$ panjang siku-sikunya maka berlaku

$$
\begin{aligned}
& a^{2}=b^{2}+c^{2} \\
& b^{2}=a^{2}-c^{2} \\
& c^{2}=a^{2}-b^{2}
\end{aligned}
$$

\section{KEMAMPUAN MENYELESAIKAN SOAL}

Tingkat keberhasilan suatu proses belajar mengajar dipengaruhi oleh banyak faktor. Diantaranya perbedaan dalam hal kapasitas untuk berkonsentrasi dalam menyelesaikan soal matematika, dan adanya perbedaan minat seorang anak, dan faktor budaya disekitar. Sebagaimana diketahui bahwa setiap siswa mempunyai kemampuan yang berbeda-beda. Ada yang memiliki kemampuan tinggi dan ada yang berkemampuan sedang ataupun rendah. Oleh karena itu, kemampuan yang penting dan diharapkan dikuasai oleh siswa adalah kemampuan menyelesaikan soal-soal matematika dengan benar. Sebagaimana diketahui bahwa matematika adalah salah satu ilmu dalam bidang yang sarat akan masalah, karena memiliki objek kajian yang abstrak berupa fakta, operasi atau prinsip.

Penyelesaian masalah merupakan inti dari pembelajaran matematika, karena kemampuannya tidak hanya digunakan untuk pembelajaran itu sendiri tetapi juga dilakukan dalam pengembangan metode kemampuan berpikir (Tayruakham, 2009). Mempelajari matematika merupakan usaha agar mampu meyelesaikan sebuah persoalan yang dihadapi. Belajar matematika di sekolah ditujukan pada peningkatan kemampuan siswa agar lebih cermat dan mudah dalam memahami dan menguasai pelajaran matematika. Kemampuan menyelesaikan soal matematika merupakan keberhasilan dalam belajar matematika. Keberhasilan seorang siswa dalam menyelesaikan soal tergantung 
pada pengetahuan dasar yang dimiliki setiap siswa. Siswa yang memiliki pengetahuan dasar yang baik akan lebih memudahkan dalam memecahkan sebuah persoalan matematika. Oleh karena itu, sebelum memulai proses pembelajaran sebaiknya setiap guru harus memberikan apersepsi kepada siswa agar setiap siswa lebih mudah memahami pengetahuan yang baru dengan bantuan pengetahuan yang telah dimiliki sebelumnya. Kemampuan menyelesaikan soal yang dimaksud dalam penelitian ini adalah ketika siswa telah mampu menyelesaikan soal yang diberikan sesuai dengan konsep yang telah diajarkan.

\title{
BANGUN RUANG SISI DATAR
}

Dalam penelitian ini permasalahan bangun ruang yang akan digunakan pada kompetensi dasar adalah menurunkan rumus untuk menentukan luas permukaan dan volume bangun ruang, hubungan antara diagonal ruang dan diagonal bidang, dan menyelesaikan masalah dalam kehidupan sehari-hari. Adapun bangun ruang yang dimaksud adalah kubus, balok, limas dan prisma.

\section{METODE PENELITIAN}

Penelitian ini merupakan penelitian kuantitatif dengan jenis ex post facto. Desain penelitian yang digunakan pada penelitian ini adalah paradigma sederhana, dimana dalam penelitian ini terdapat satu variabel independen dan satu variabel dependen. Populasi dalam penelitian ini adalah seluruh siswa kelas VIII MTs Negeri Balang-Balang yang berjumlah 204 orang. Dalam menentukan jumlah ukuran sampel, jika populasinya di atas 1.000 sampelnya sekitar $10 \%$, tetapi jika populasinya 100, sampelnya paling sedikit $30 \%$, dan kalau ukuran populasinya 30 maka sampelnya harus $100 \%$. Dalam penelitian ini jumlah populasinya adalah 204, jadi ukuran sampelnya 50\% atau 102 orang, dan teknik pengambilan sampelnya dengan simple random sampling.

Instrumen penelitian yang digunakan dalam penelitian ini yaitu instrumen tes berupa soal uraian mengenai materi teorema Pythagoras dan instrumen tes berupa soal uraian mengenai bangun ruang sisi datar.

\author{
HASIL DAN PEMBAHASAN
}

Deskripsi Tingkat Penguasaan Konsep Teorema Pythagoras Pada Siswa Kelas VIII MTs Negeri Balang-Balang 
Berikut ini adalah tabel hasil analisis deskriptif data pengaruh penguasaan konsep teorema Pythagoras siswa kelas VIII MTs Negeri BalangBalang.

Tabel 1. Statistik Deskriptif Penguasaan Konsep Teorema Pythagoras Siswa Kelas VIII MTs Negeri Balang-Balang

\begin{tabular}{cc}
\hline Statistik & $\begin{array}{c}\text { Penguasaan Konsep } \\
\text { Teorema Pythagoras }\end{array}$ \\
\hline Jumlah Sampel & 102 \\
Nilai Terendah & 23 \\
Nilai Tertinggi & 91 \\
Rata-rata & 60,14 \\
Standar Deviasi & 13,699 \\
\hline
\end{tabular}

Dari tabel di atas, selanjutnya menyusun tabel kategori data pengaruh penguasaan konsep teorema Pythagoras siswa kelas VIII MTs Negeri BalangBalang dan akan disajikan dalam bentuk tabel berikut:

Tabel 2. Distribusi Frekuensi dan Persentase Penguasaan Konsep Teorema Pythagoras Siswa Kelas VIII MTs Negeri Balang-Balang

\begin{tabular}{ccccc}
\hline No & Interval & Frekuensi & Persentase & $\begin{array}{c}\text { Kategori penguasaan } \\
\text { konsep teorema Pythagoras }\end{array}$ \\
\hline 1 & $0-20$ & 0 & $0 \%$ & Sangat rendah \\
2 & $20-40$ & 4 & $3,9 \%$ & Rendah \\
3 & $40-60$ & 38 & $37,2 \%$ & Sedang \\
4 & $60-80$ & 52 & $50,9 \%$ & Tinggi \\
5 & $80-100$ & 8 & $7,8 \%$ & Sangat tinggi \\
\hline & Jumlah & 102 & 100 & \\
\hline
\end{tabular}

Berdasarkan tabel di atas dapat disimpulkan bahwa skor pengusaan konsep teorema Pythagoras termasuk kategori tinggi dengan presentase 50,9\%.

\section{Deskripsi Kemampuan Menyelesaikan Soal-Soal Bangun Ruang Sisi Datar Siswa Kelas VIII MTs Negeri Balang-Balang \\ Berikut ini adalah tabel hasil analisis deskriptif data pengaruh penguasaan konsep teorema Pythagoras siswa kelas VIII MTs Negeri Balang- Balang.}

Tabel 3. Statistik Deskriptif Kemampuan Menyelesaikan Soal-Soal Bangun Ruang Sisi Datar Siswa Kelas VIII MTs Negeri Balang-Balang 


\begin{tabular}{cc}
\hline Statistik & $\begin{array}{c}\text { Kemampuan Menyelesaikan Soal- } \\
\text { Soal Bangun Ruang Sisi Datar }\end{array}$ \\
\hline Jumlah Sampel & 102 \\
Nilai Terendah & 30 \\
Nilai Tertinggi & 90 \\
Rata-rata & 61,70 \\
Standar Deviasi & 13,198 \\
\hline
\end{tabular}

Dari tabel di atas, selanjutnya menyusun tabel kategori data pengaruh penguasaan konsep teorema Pythagoras siswa kelas VIII MTs Negeri BalangBalang dan akan disajikan dalam bentuk tabel berikut:

Tabel 4. Distribusi Frekuensi dan Persentase Kemampuan Menyelesaikan Soal-soal Bangun Ruang Sisi Datar Siswa Kelas VIII MTs Negeri Balang-Balang

\begin{tabular}{ccccc}
\hline No & Interval & Frekuensi & Persentase & $\begin{array}{c}\text { Kemampuan Menyelesaikan } \\
\text { Soal-Soal Bangun Ruang } \\
\text { Sisi Datar }\end{array}$ \\
\hline 1 & $0-20$ & 0 & $0 \%$ & Sangat rendah \\
2 & $20-40$ & 5 & $4,9 \%$ & Rendah \\
3 & $40-60$ & 34 & $33,3 \%$ & Sedang \\
4 & $60-80$ & 56 & $54,9 \%$ & Tinggi \\
5 & $80-100$ & 7 & $6,8 \%$ & Sangat tinggi \\
\hline & Jumlah & 100 & $100 \%$ & \\
\hline
\end{tabular}

Berdasarkan tabel di atas dapat disimpulkan bahwa skor pengusaan konsep teorema Pythagoras termasuk kategori tinggi dengan presentase $54 \%$.

\section{Uji Normalitas}

Tabel 5. Hasil Uji Normalitas

\begin{tabular}{ccc}
\hline Variabel & Sig & Keterangan \\
\hline $\begin{array}{c}\text { Penguasaan Konsep Teorema Pythagoras }(\mathrm{X}) \\
\text { Kemampuan Menyelesaikan Soal-Soal } \\
\text { Bangun Ruang Sisi Datar }(\mathrm{Y})\end{array}$ & 0,071 & Normal \\
\hline
\end{tabular}


Berdasarkan hasil pengolahan dengan SPSS 20.0 di atas maka disimpulkan bahwa ketiga variabel tersebut berdistribusi normal karena nilai sig. lebih besar dari $\alpha$ atau (sig. $>0,05$ ).

\section{Uji Linearitas}

Tabel 6. Uji Linearitas Pengaruh Penguasaan Konsep Teorema Pythagoras Terhadap Kemampuan Menyelesaikan Soal-Soal Bangun Ruang Sisi Datar

\begin{tabular}{cccc}
\hline Regresi & F & Sig. & Keterangan \\
\hline XY & 0,938 & 0,538 & Linear \\
\hline
\end{tabular}

Berdasarkan tabel diatas menunjukkan bahwa hasil uji linearitas penguasaan konsep teorema Pythagoras terhadap kemampuan menyelesaikan soal-soal bangun ruang sisi datar diperoleh hasil sig 0,583> a $(0,05)$ berarti penguasaan konsep teorema pythagoras terhadap kemampuan menyelesaikan soal-soal bangun ruang sisi datar adalah linear.

\section{Analisis Regresi Linear Sederhana}

Tabel 7. Uji Signifikansi Koefisien Regresi Linier Sederhana

\begin{tabular}{ccc}
\hline Model & $\mathbf{R}$ & $\boldsymbol{R}^{\mathbf{2}}$ \\
\hline $\mathrm{XY}$ & 0,546 & 0,298 \\
\hline
\end{tabular}

Berdasarkan tabel di atas, angka R² (R Square) sebesar 0,298 atau (29,8\%). Hal ini menunjukkan bahwa persentase penguasaan konsep teorema pythagoras terhadap kemampuan menyelesaikan soal-soal bangun ruang sisi datar sebesar 29,8\% Hasil penelitian dengan analisis regresi linear sederhana menunjukkan bahwa terdapat pengaruh yang signifikan antara penguasaan konsep teorema Pythagoras dengan terhadap kemampuan menyelesaikan soalsoal bangun ruang sisi datar dengan sumbangan persentase sebesar 0,298 $(29,8 \%)$ sedangkan sisanya sebesar $70,2 \%$ dipengaruhi atau dijelaskan oleh variabel lain yang tidak dimasukkan dalam penelitian ini. Selain itu Berdasarkan hasil analisis inferensial pada uji hipotesis regresi linear sederhana diperoleh $t_{\text {hitung }}=6,42>t_{\text {tabel }}=1,983$. Maka berdasarkan kriteria pengujian dapat dikatakan bahwa ada pengaruh positif penguasaan konsep teorema Pythagoras terhadap kemampuan menyelesaikan soal-soal bangun ruang sisi 
datar siswa kelas VIII MTs Negeri Balang-Balang, dengan koefisien determinasi sebesar $29,8 \%$.

Hasil penelitian ini sejalan dengan penelitian Muchyidin dan Ahmad Hildan, menyimpulkan bahwa terdapat pengaruh penguasaan teorema Pythagoras terhadap kemampuan siswa dalam menyelesaikan soal-soal garis singgung lingkaran.

\section{SIMPULAN}

Berdasarkan hasil penelitian dan pembahasan, maka dapat ditarik kesimpulan bahwa secara umum tingkat penguasaan konsep teorema Pythagoras siswa kelas VIII MTs Negeri Balang-Balang berada pada kategori tinggi. Hal ini ditunjukkan dari perolehan persentase pada kategori tinggi sebesar 50,9 \% dengan nilai rata-rata 60,14. Sedangkan tingkat kemampuan menyelesaikan soal-soal bangun ruang sisi datar siswa kelas VIII MTs Negeri Balang-Balang pada kategori tinggi. Hal ini ditunjukkan dari perolehan persentase pada kategori tinggi sebesar 54,9\% dengan nilai rata-rata 61,70 .

Berdasarkan hasil analisis statistik inferensial menggunakan analisis regresi linear sederhana menyimpulkan bahwa terdapat pengaruh penguasaan konsep teorema Pythagoras dengan terhadap kemampuan menyelesaikan soalsoal bangun ruang sisi datar dengan sumbangan persentase sebesar 0,298 $(29,8 \%)$ sedangkan sisanya sebesar $70,2 \%$ dipengaruhi atau dijelaskan oleh variabel lain yang tidak dimasukkan dalam penelitian ini.

\section{DAFTAR PUSTAKA}

Afifah, D. S. N. (2013). “Identifikasi kemampuan siswa dalam menyelesaikan soal aritmatika sosial ditinjau dari perbedaan kemampuan matematika. (Online). Jurnal Pendidikan Matematika STKIP PGRI Sidoarjo, 1(1).

Dahar, R. W. (2011). Teori-teori belajar \& pembelajaran. Jakarta: Erlangga.

Danim, S. (2010). Pengantar kependidikan. Bandung: Alfabeta.

Hamzah, A. \& Muhlisrarini. (2014). Perencanaan dan strategi pembelajaran matematika. Jakarta: PT Raja Grafindo Persada.

Muchyidin, A. \& Amin, A. H. F. (2012) “Pengaruh penguasaan teorema Pythagoras terhadap kemampuan menyelesaikan soal-soal garis singgung lingkaran kelas VIII SMPN 1 Leuwimunding." Jurnal Online Eduma Volume 1 No. 2 Tahun 2012. 
Putra, A. R., dkk. (2014). The analysis of concepts mastery and critical thinking skills on invertebrate zoology course. International Journal of Science and Research, 3.

Rohim, N. (2011). Pengaruh penguasaan konsep bangun datar terhadap kemampuan peserta didik dalam menyelesaikan soal-soal bangun ruang sisi datar kelas VIII MTs Nahdlatut Thullab Manggarwetan Godong Grobogan. Skripsi. Fakultas Tarbiyah IAIN Walisongo Semarang.

Sood, V. (2013). "Effect of mastery learning strategies on concept attainment in geometry among high school students." International Journal of Behavioral Social and Movement Sciences, 2(2).

Susanto, A. (2013). Teori belajar pembelajaran di sekolah dasar, Jakarta: Kencana Prenada Media Group.

Tayruakham, S., dkk. (2009). Factors influencing mathematic problem-solving ability of sixth grade students. Journal of Social Sciences.

Tirtarahrdja, U. \& Sulo, S. L. L. (2015). Pengantar pendidikan, Cet. II; Jakarta: PT Rineka Cipta. 